\title{
UMODL1 wt Allele
}

National Cancer Institute

\section{Source}

National Cancer Institute. UMODL1 wt Allele. NCI Thesaurus. Code C150347.

Human UMODL1 wild-type allele is located in the vicinity of 21q22.3 and is approximately

$112 \mathrm{~kb}$ in length. This allele, which encodes uromodulin-like 1 protein, is involved in calcium binding. 